LIVER

\title{
Endothelin receptor antagonist TAK-044 arrests and reverses the development of carbon tetrachloride induced cirrhosis in rats
}

\author{
C Thirunavukkarasu, Y Yang, V M Subbotin, S A K Harvey, J Fung, C R Gandhi
}

See end of article for authors' affiliations .....................

Correspondence to: Dr C R Gandhi, Thomas E Starzl Transplantation Institute, University of Pittsburgh, E-1540 BST, 200 Lothrop St, Pittsburgh, PA 15213, USA:

Gandhics@msx.upmc.edu

Accepted for publication 8 January 2004

\begin{abstract}
Background and aims: Hepatic concentrations of the powerful vasoconstrictor and fibrogen endothelin 1 (ET-1) and its receptors increase in human and experimental cirrhosis, suggesting a major role for ET-1 in the pathology of chronic liver disease. We investigated whether ET-1 receptor antagonism, after the development of fibrosis and cirrhosis, arrests/reverses the progression of chronic liver disease.

Methods: Chronic liver injury was induced in rats by carbon tetrachloride $\left(\mathrm{CCl}_{4}\right)$ treatment $(0.15 \mathrm{ml} / \mathrm{kg}$ intraperitoneally twice a week) in conjunction with phenobarbital in drinking water $(0.4 \mathrm{~g} / \mathrm{l})$ for four (group 1: fibrosis) and eight (group 2: cirrhosis) weeks. Rat were then treated concurrently with the ET-1 receptor antagonist TAK-044 $(10 \mathrm{mg} / \mathrm{kg} /$ day $)$ and $\mathrm{CCl}_{4} /$ phenobarbital for a further four weeks.

Results: Histopathological examination revealed significant arrest of progression to cirrhosis in group 1 and reversal of cirrhosis in group 2 rats. TAK-044 treatment caused significant amelioration of portal hypertension, systemic hypotension, and liver injury (reduced activities of serum aspartate aminotransferase, alanine aminotransferase, and lactate dehydrogenase), and improved hepatic synthetic capacity (increased serum albumin concentration) in both groups of rats relative to vehicle treated rats. TAK-044 treatment reduced collagen synthesis, as evidenced by decreased hepatic hydroxyproline content, mRNA expression of collagen- $\alpha$ type $\mathrm{l}$, and tissue inhibitors of matrix metalloproteinases 1 and 2 , and mRNA and protein expression of a potent fibrogenic cytokine, transforming growth factor $\beta 1$.

Conclusions: The results emphasise the role of ET-1 in the development of cirrhosis and strongly suggest that blockade of its actions can be a rational therapy for chronic liver disease and its complications.
\end{abstract}

$\mathrm{T}$ he causative mechanisms of liver cirrhosis and associated portal hypertension have been investigated extensively in the hope of developing more effective pharmacological and surgical therapies. Endothelin l (ET-1) is the most potent constrictor of the hepatic vasculature, ${ }^{1}$ and has been implicated in fibrotic remodelling of major organs. ${ }^{2-5}$ Hepatic concentrations of ET-l and its receptors increase in human ${ }^{6-8}$ and experimental ${ }^{910}$ cirrhosis. Furthermore, ET-1 increases circulating and hepatic levels of the potent hypotensive agent platelet activating factor (PAF) in cirrhosis, ${ }^{11}{ }^{12}$ perhaps contributing to systemic hypotension.

Of the two main ET-l receptor subtypes, $\mathrm{ET}_{\mathrm{A}}$ on vascular smooth muscle cells causes vasoconstriction while $\mathrm{ET}_{\mathrm{B}}$ on endothelial cells normally causes vasorelaxation via nitric oxide (NO). Interestingly, $\mathrm{ET}_{\mathrm{B}}$ stimulation appears to play a major role in hepatic vasoconstriction ${ }^{13}$ with the pure $\mathrm{ET}_{\mathrm{B}}$ agonist sarafotoxin S6c causing a greater increase in portal pressure in cirrhotic rats than in control rats. ${ }^{14}{ }^{15}$ Moreover, ET-1 elicits contraction of perisinusoidal stellate cells via both receptor subtypes ${ }^{76}$ and stimulates the synthesis of transforming growth factor $\beta$ (TGF- $\beta$ ) and collagen via $\mathrm{ET}_{\mathrm{A}}$ and $\mathrm{ET}_{\mathrm{B}}$ receptors, respectively. ${ }^{17}$ Collectively, these findings strongly suggest that ET-1, by acting via both receptor subtypes, is an integral part of the structural and haemodynamic abnormalities of liver cirrhosis.

Carbon tetrachloride $\left(\mathrm{CCl}_{4}\right)$ induced cirrhosis in rats, which exhibits several characteristics of human liver disease, including excessive fibrosis with uniform micronodular transformation, portal hypertension, ascites, and hyperdynamic circulation, ${ }^{18-20}$ has been used extensively to investigate the biochemical and molecular mechanisms of the development and complications of cirrhosis. An $\mathrm{ET}_{\mathrm{A}}$ antagonist LU135252 was found to ameliorate experimental biliary fibrosis but caused significant mortality due to its renal toxicity, particularly when the dose of the antagonist was increased. ${ }^{21}$ Other studies reported that $\mathrm{ET}_{\mathrm{A}}$ antagonism does not affect portal hypertension in cirrhotic rats ${ }^{22}$ and worsens hepatic microcirculatory changes and necrosis in endotoxin treated rats. ${ }^{23}$ On the other hand, portal administration of the $\mathrm{ET}_{\mathrm{B}}$ agonist sarafotoxin $\mathrm{S6C}$ exacerbates portal hypertension. ${ }^{15}$ However, short term portal infusion of $\mathrm{ET}_{\mathrm{A}}+\mathrm{ET}_{\mathrm{B}}$ antagonists in cirrhotic rats reduces portal hypertension, ${ }^{10} 1424$ and antagonism of both receptors ameliorates endotoxin induced liver injury. ${ }^{25}$ It is not known if long term antagonism of both receptors can be used in treating fibrosis and portal hypertension without eliciting toxic effects. Recently, we found that spontaneous resolution of $\mathrm{CCl}_{4}$ induced cirrhosis was accelerated by treatment with a mixed $\mathrm{ET}_{\mathrm{A}}+\mathrm{ET}_{\mathrm{B}}$ antagonist TAK-044 (cyclo(D- $\alpha$-aspartyl-3( (-4-phenylpiperazin-1-yl)carbonyl)L-alanyl-L- $\alpha$-aspartyl-D-2(2-thienyl)glycyl-L-Leucyl-D-tryptophyl)disodium salt). ${ }^{26}$ In the present study, we show that long term treatment with TAK-044 concurrent with chronic $\mathrm{CCl}_{4}$ treatment not only arrests the progression of fibrosis to cirrhosis but also reverses cirrhosis without eliciting toxic effects.

Abbreviations: ET, endothelin; MAP, mean arterial pressure; MMP, matrix metalloproteinase; NO, nitric oxide; PAF, platelet activating factor; SMA, smooth muscle actin; TGF, transforming growth factor; TIMP, tissue inhibitors of metalloproteinases; $\mathrm{CCl}_{4}$, carbon tetrachloride; TGF- $\beta$, transforming growth factor $\beta ; \gamma$-GT, $\gamma$-glutamyl transferase; LDH, lactate dehydrogenase; ALP, alkaline phosphatase; AST, aspartate aminotransferase; ALT, alanine aminotransferase; RT-PCR, reverse transcriptase-polymerase chain reaction; QRT-PCR, quantitative real time PCR; ECM, extracellular matrix 

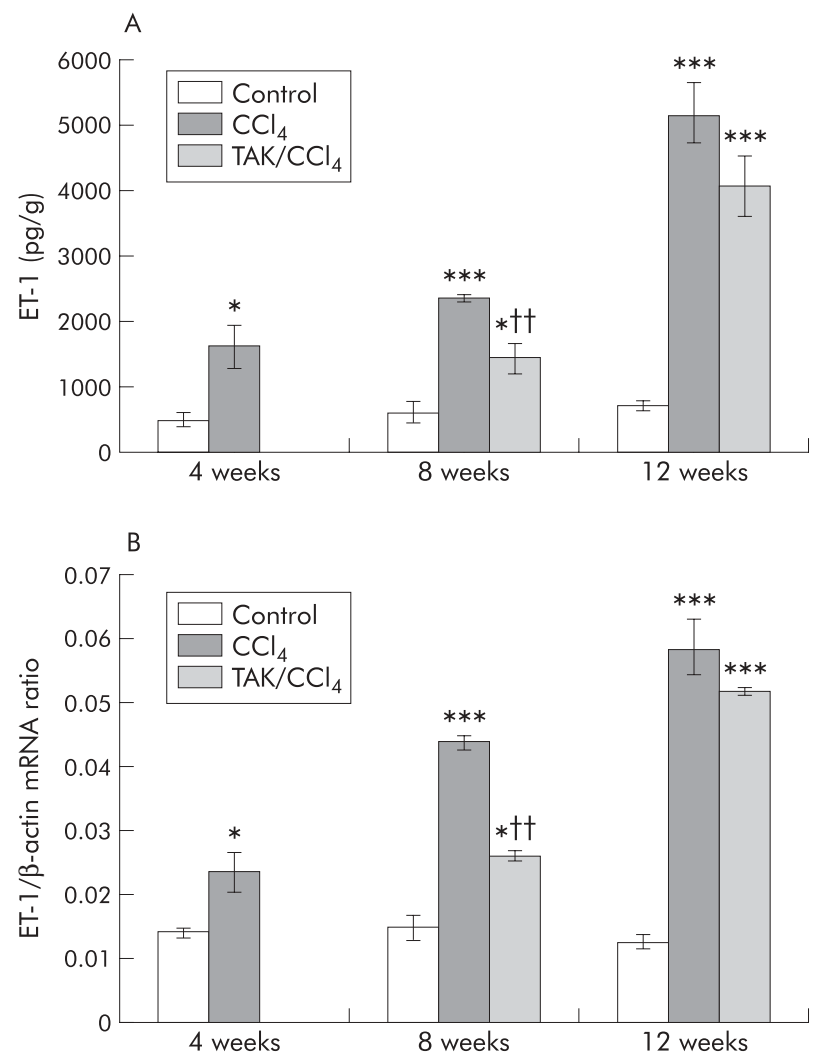

Figure 1 Effect of carbon tetrachloride $\left(\mathrm{CCl}_{4}\right)$ and TAK-044 treatment on hepatic endothelin 1 (ET-1) and preproET-1 mRNA. Rats were treated with $\mathrm{CCl}_{4}$ for 4,8 , and 12 weeks. During $\mathrm{CCl}_{4}$ treatment between four and eight weeks and eight and 12 weeks, $50 \%$ of the rats each received TAK-044 or saline. Hepatic ET-1 content and mRNA expression of preproET-1 were determined in tissue samples from three rats in each group, each assay performed in triplicate. Details are described in the methods section. (A) Hepatic ET-1 concentration. (B) Hepatic preproET-1 mRNA expression normalised with respect to that of $\beta$-actin with equal amounts of cDNA used in the polymerase chain reaction. ${ }^{*} p<0.05$, *** $\mathrm{p}<0.001$ versus control; $\uparrow \uparrow \mathrm{p}<0.01$ versus $\mathrm{CCl}_{4}$.

\section{MATERIALS AND METHODS \\ Induction of liver cirrhosis}

The experimental protocols were approved by the University of Pittsburgh Institutional Animal Care and Use Committee according to the guidelines of the National Institutes of Health. Chronic liver injury was induced in male SpragueDawley rats $(230-250 \mathrm{~g})$, as described previously, ${ }^{10}$ by $\mathrm{CCl}_{4}$ administration $(0.15 \mathrm{ml} / \mathrm{kg}$ intraperitoneally twice a week) in conjunction with phenobarbital $(0.4 \mathrm{~g} / \mathrm{l})$ in drinking water. Control rats received injection of the carrier (peanut oil) and phenobarbital water. At the end of four weeks of treatment, femoral arterial and portal venous pressures were measured in three control and three $\mathrm{CCl}_{4}$ treated rats, as described previously. ${ }^{1025} 26$ Briefly, under pentobarbital anaesthesia, a PE-50 catheter was inserted into the femoral artery to monitor arterial blood pressure. The hepatic trigone was exposed via laparotomy and the portal vein was skeletonised. The intestines and abdominal cavity were covered with warm saline soaked sponges during the entire experimental period. A 23 gauge needle in a PE-50 catheter was inserted into the portal vein to measure portal pressure. After stable recordings of arterial and portal venous pressure, blood was drawn from the femoral artery. The liver was excised, washed in ice cold phosphate buffered saline, and snap frozen in liquid nitrogen, after storing a slice of left lateral lobe in $10 \%$ buffered formalin.
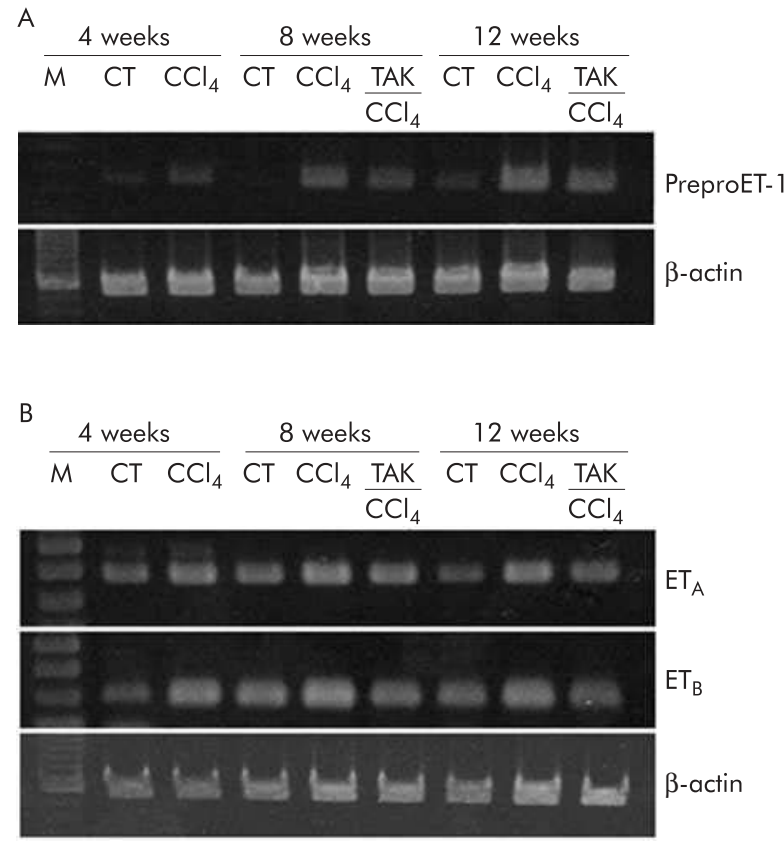

Figure 2 Representative gels showing reverse transcriptase-polymerase chain reaction analysis of liver samples for prepro-endothelin 1 (preproET-1), and endothelin receptor $A$ and $B\left(E T_{A}\right.$ and $\left.E T_{B}\right)$ mRNA, and of $\beta$-actin mRNA using the same concentration of CDNA.

The remaining $\mathrm{CCl}_{4}$ treated rats were randomly distributed into two groups. In one group, Alzet osmotic minipumps containing saline or a solution of TAK-044 were inserted into the peritoneal cavity via a small incision in the abdomen. Fifty per cent each of the $\mathrm{CCl}_{4}$ treated rats received TAK-044 $\left(10 \mathrm{mg} / \mathrm{kg} /\right.$ day) or saline, while continuing $\mathrm{CCl}_{4}$ treatment. At the end of eight weeks livers of seven saline $+\mathrm{CCl}_{4}$ treated, seven TAK- $044+\mathrm{CCl}_{4}$ treated, and three control rats were processed as described above, after blood pressure measurements and blood withdrawal.

In the other group of $\mathrm{CCl}_{4}$ treated rats, the above procedure was repeated at the end of eight weeks; seven saline $+\mathrm{CCl}_{4}$ treated, seven TAK-044+CCl 4 treated, and three control rats were used at the end of 12 weeks.

\section{Determination of ET- 1 and its receptors}

ET-1 was extracted and its concentration measured by ELISA (Peninsula Laboratories, Sunnyvale, California, USA). Hepatic ET- 1 receptors were determined by saturation and competition binding assays, essentially as described previously. ${ }^{625}$

\section{Biochemical parameters}

Serum total protein, albumin, bilirubin, $\gamma$-glutamyl transferase $(\gamma-\mathrm{GT})$, lactate dehydrogenase $(\mathrm{LDH})$, alkaline phosphatase (ALP), aspartate aminotransferase (AST), and alanine aminotransferase (ALT) were estimated using a kit from Stanbio Laboratory (Boerne, Texas, USA).

\section{Morphology and scoring of liver cirrhosis}

Sections of $4 \mu \mathrm{m}$ thickness were prepared from formalin fixed liver slices embedded in paraffin and stained with haematoxylin-eosin and Masson's trichrome stain. ${ }^{27}$ Liver pathology was graded by VMS in a blinded manner using an established scoring system, as described previously ${ }^{26}$; a score of " 5 " was considered as complete cirrhosis and " 0 " as normal. Sections were also treated with anti- $\alpha$-smooth muscle actin (SMA) antibody (Dako, Carpinteria, California, USA; 
smooth muscle actin-1A4) to determine activated stellate cells/myofibroblasts, ${ }^{28}$ as described previously. ${ }^{26}{ }^{29}$

\section{Determination of RNA expression}

Relative mRNA expressions of preproET-1, ET-1 receptors, collagen $\alpha$ type I, and TGF- $\beta 1$ were determined by semiquantitative reverse transcriptase-polymerase chain reaction (RT-PCR), essentially as described previously. ${ }^{26}$ The same amount of cDNA was used to determine expression of $\beta$-actin mRNA for normalisation. The number of PCR cycles employed was in the linear range of the reaction for each product.

Quantitative real time PCR (QRT-PCR) was performed for mRNA expression of tissue inhibitors of metalloproteinases (TIMPs) using a Prism 7700 Sequence Detector from Applied Biosystems Inc. (ABI, Foster City, California, USA) with data acquisition and analysis by Sequence Detector software $\mathrm{v}$. 1.7a. Assay of cDNA levels was performed using Taqman Universal Master Mix (ABI) and the primer probe sets from Invitrogen (Rockville, Maryland, USA). Primers were designed using Primer Express software (ABI). Threshold cycle numbers were determined for TIMP-1 and TIMP-2 and corrected using the equivalent data for $\beta$-actin.

\section{Determination of hydroxyproline and collagenase}

Hepatic hydoxyproline content was measured as described previously using the chloramine T/p-dimethylaminobenzaldehyde procedure. ${ }^{26}{ }^{30}$

For determination of collagenase, the liver was homogenised in $0.3 \mathrm{M}$ Tris $\mathrm{HCl}$ buffer $(\mathrm{pH} 7.4)$ and centrifuged at $200 \mathrm{rpm}$ for five minutes. Enzyme activity was determined in the supernatant with an assay kit from Chemicon International Inc (Temecula, California, USA) which measures matrix degrading metalloproteinases (MMP)-1, MMP-8, and MMP-13, but not gelatinases (MMP-2).

\section{Determination of TGF- $\beta 1$}

The liver was homogenised in $2.5 \mathrm{~N}$ acetic acid containing $10 \mathrm{M}$ urea, $100 \mu \mathrm{g} / \mathrm{ml} \mathrm{PMSF}$, and $10 \mu \mathrm{g} / \mathrm{ml}$ pepstatin, and incubated for 20 minutes at room temperature in polypropylene tubes. After neutralisation with $2.7 \mathrm{~N} \mathrm{NaOH}$ in $1 \mathrm{M}$ HEPES, the homogenate was centrifuged at $20190 \mathrm{~g}$ for 20 minutes. TGF- $\beta 1$ content was determined in the supernatant by ELISA (Promega, Madison, Wisconsin, USA).

\section{Statistical analysis}

Results are expressed as mean (SEM). Physiological, histopathological, and biochemical findings represent averages of seven rats $\left(\mathrm{CCl}_{4}\right.$ or $\mathrm{CCl}_{4}+\mathrm{TAK}-044$ treatment $)$ and three rats (control) for each time point. Results of molecular assays represent averages of samples from at least three rats in each group, each analysed in duplicate or triplicate. Statistical significance was derived by the non-parametric MannWhitney two tailed variance test using the SPSS program to determine significance between multiple groups. A p value of $<0.05$ was considered statistically significant.

\section{RESULTS}

\section{Endothelin and its receptors}

Hepatic concentrations of ET-1 increased by threefold, fourfold, and sevenfold, respectively, after 4, 8, and 12 weeks of $\mathrm{CCl}_{4}$ treatment (fig $\mathrm{lA}$ ); similar increases were also observed in the preproET-1 mRNA transcript (figs 1B, 2A). ET- 1 concentration was $40 \%$ and $20 \%$ less in TAK-044 treated rats than in saline treated rats at eight and 12 weeks, respectively.

$\mathrm{ET}_{\mathrm{A}}$ receptor density increased by $40 \%, 60 \%$, and $80 \%$ after 4,8 , and 12 weeks of $\mathrm{CCl}_{4}$ treatment, respectively (fig 3A). $\mathrm{ET}_{\mathrm{B}}$ receptor density increased by 1.5 -fold at four weeks, and by 3.5 -fold at eight and 12 weeks of $\mathrm{CCl}_{4}$ treatment (fig 3C). TAK-044 treatment between four and eight weeks or eight
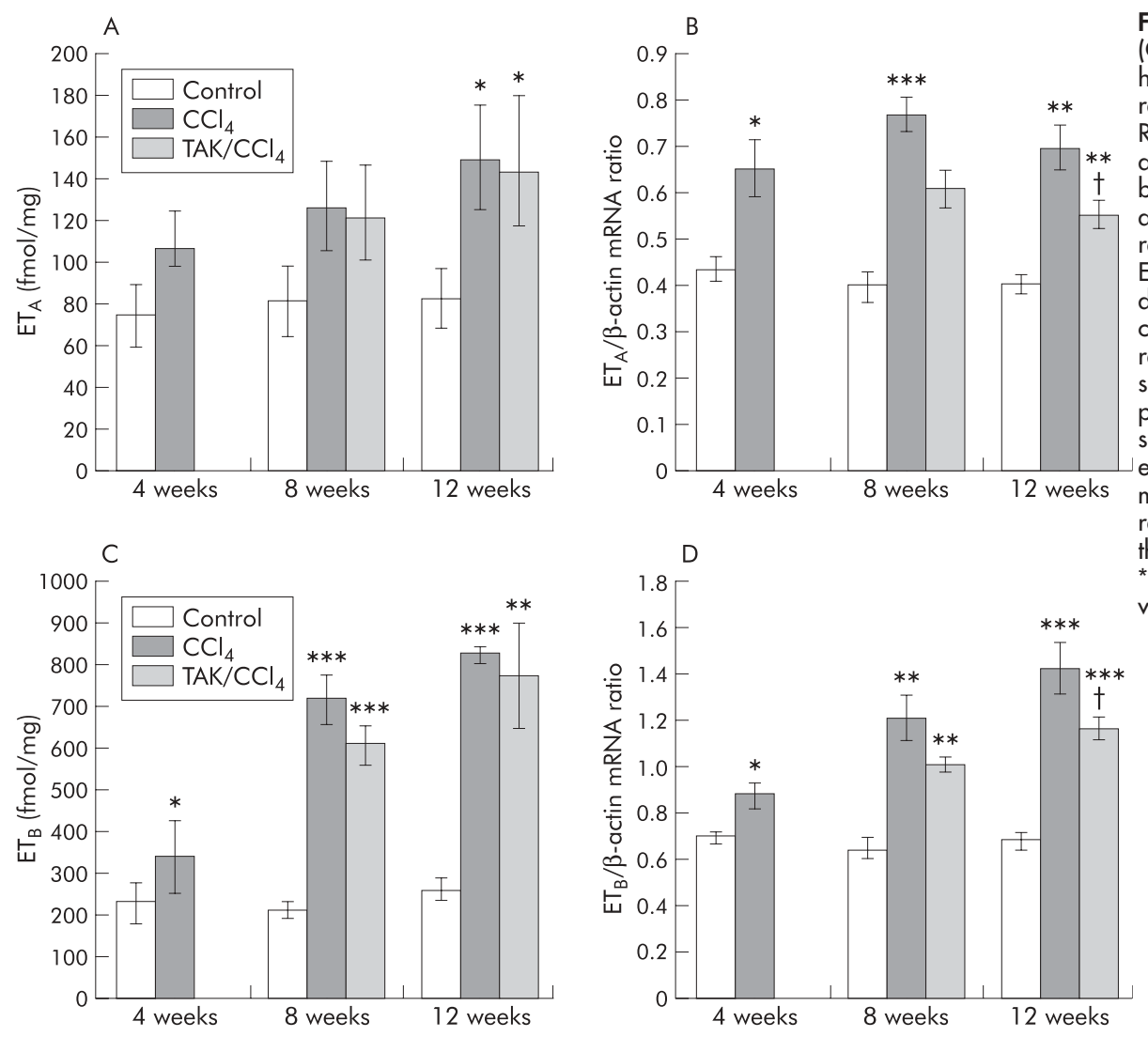

Figure 3 Effect of carbon tetrachloride $\left(\mathrm{CCl}_{4}\right)$ and TAK-044 treatment on hepatic endothelin (ET) $\mathrm{ET}_{A}$ and $\mathrm{ET}_{B}$ receptors and their $\mathrm{mRNA}$ expression. Rats were treated with $\mathrm{CCl}_{4}$ for 4,8 , and 12 weeks. During $\mathrm{CCl}_{4}$ treatment between four and eight weeks or eight and 12 weeks, $50 \%$ of rats each received TAK-044 or saline. Hepatic $\mathrm{ET}_{\mathrm{A}}$ receptor $(\mathrm{A})$ and $\mathrm{ET}_{B}$ receptor $(\mathrm{C})$ densities were determined by competition binding analysis and relative $m R N A$ expression by semiquantitative reverse transcriptasepolymerase chain reaction in tissue samples from three rats in each group, each assay performed in triplicate. mRNA expression of respective receptors normalised with respect to that of $\beta$-actin are shown in (B) and (D). ${ }^{*} p<0.05,{ }^{* *} p<0.01,{ }^{* *} p<0.001$ versus control; $\mathrm{tp}<0.05$ versus $\mathrm{CCl}_{4}$. 
Table 1 General characteristics of the study animals

\begin{tabular}{|c|c|c|c|c|c|c|c|c|}
\hline & \multicolumn{2}{|l|}{4 weeks } & \multicolumn{3}{|l|}{8 weeks } & \multicolumn{3}{|l|}{12 weeks } \\
\hline & Control & $\mathrm{CCl}_{4}$ & Control & $\mathrm{CCl}_{4}$ & $\mathrm{TAK}+\mathrm{CCl}_{4}$ & Control & $\mathrm{CCl}_{4}$ & $\mathrm{TAK}+\mathrm{CCl}_{4}$ \\
\hline $\begin{array}{l}\text { Body wt (g) } \\
\text { Spleen wt (g) }\end{array}$ & $\begin{array}{l}360(4) \\
0.83(0.03)\end{array}$ & $\begin{array}{l}270(22)^{*} \\
0.77(0.1)\end{array}$ & $\begin{array}{l}390(12) \\
0.86(0.05)\end{array}$ & $\begin{array}{l}313(16)^{*} \\
1.5(0.21)^{*}\end{array}$ & $\begin{array}{l}332(9)^{*} \\
1.17(0.03)^{\star}\end{array}$ & $\begin{array}{l}416(16) \\
0.83(-0.06)\end{array}$ & $\begin{array}{l}291(22)^{*} \\
1.38(0.3)^{*}\end{array}$ & $\begin{array}{l}388(9) \dagger \\
1.34(0.19)^{*}\end{array}$ \\
\hline Ascites (g) & - & - & - & $11(3)$ & $5(3)$ & - & $86(15)$ & $21(6) \dagger$ \\
\hline \multicolumn{9}{|l|}{ Serum } \\
\hline Protein (g/dl) & $7.13(0.1)$ & $6.43(0.1)^{*}$ & $7.1(0.1)$ & $6.5(0.12)^{*}$ & $6.7(0.3)$ & $7.1(0.1)$ & $5.9(0.2)^{*}$ & $6.9(0.2) \dagger$ \\
\hline Albumin (g/dl) & $4.73(0.03)$ & $4.34(0.06)^{*}$ & $4.7(0.09)$ & $3.99(0.17)^{*}$ & $4.38(0.11)$ & $4.61(0.10)$ & $3.62(0.13)^{*}$ & $4.51(0.08) \dagger$ \\
\hline Bilirubin (mg/dl) & $2.85(0.1)$ & $3.5(0.16)^{*}$ & $2.83(0.08)$ & $3.62(0.1)^{\star *}$ & $3.02(0.14)$ & $2.89(0.13)$ & $3.73(0.1)^{*}$ & $3.14(0.09) \dagger$ \\
\hline $\mathrm{LDH}(\mathrm{U} / \mathrm{dl})$ & 284 (17) & $424(24)^{*}$ & $268(19)$ & $397(17)^{*}$ & 296 (13)t & 285 (13) & $413(15)^{*}$ & $328(11) \dagger$ \\
\hline ALT (U/d) & 19 (1) & $54(3)^{\star \star \star *}$ & $18(1)$ & $306(22)^{\star \star * *}$ & $172(12)^{* * *} \dagger$ & $23(2)$ & $268(19)^{* * *}$ & $117(16)^{*} \dagger$ \\
\hline AST (U/dl) & 47 (1) & $113(10)^{* * *}$ & 71 (4) & $251(15)^{\star \star *}$ & $184(9)^{* * *} \dagger$ & $44(6)$ & $384(15)^{* * *}$ & $164(21)^{*} \dagger$ \\
\hline $\operatorname{ALP}(\mathrm{U} / \mathrm{d})$ & $54(2)$ & $60(3)$ & $53(2)$ & $181(8)^{* * *}$ & $146(10)^{* * *}$ & $45(6)$ & $255(14)^{* * *}$ & $162(11)^{* \star} \dagger$ \\
\hline$\gamma-\mathrm{GT}(\mathrm{U} / \mathrm{d} \mathrm{d})$ & $1.7(0.3)$ & $14.0(1.3)^{* *}$ & $1.3(0.1)$ & $17.2(1.2)^{* * *}$ & $7.1(0.6)^{* *} \dagger$ & $2.1(0.3)$ & $27.3(2.6)^{* * *}$ & $5.9(1.2)^{*}+\dagger$ \\
\hline
\end{tabular}

Rats were treated with vehicle or carbon tetrachloride $\left(\mathrm{CCl}_{4}\right)$ for 4,8 , and 12 weeks. In the last two groups, $50 \%$ of rats each were treated with TAK-044 or saline between four and eight weeks or eight and 12 weeks. Various determinations were made, as described in the methods section.

Results are means (SEM) of three control, seven $\mathrm{CCl}_{4}$ treated, and seven TAK-044+CCl $\mathrm{Cl}_{4}$ treated rats.

For biochemical parameters, each assay was performed in duplicate for each rat. LDH, lactate dehydrogenase; ALT, alanine aminotransferase; AST, aspartate aminotransferase; ALP, alkaline phosphatase; $\gamma$-GT, $\gamma$-glutamyl transferase.

${ }^{*} \mathrm{p}<0.05,{ }^{* *} \mathrm{p}<0.01,{ }^{* * *} \mathrm{p}<0.001$ versus control; $\mathrm{tp}<0.05,+\mathrm{t} p 0.01$ versus $\mathrm{CCl}_{4}$.

and 12 weeks did not alter $\mathrm{ET}_{\mathrm{A}}$ or $\mathrm{ET}_{\mathrm{B}}$ receptor density. $\mathrm{ET}_{\mathrm{A}}$ receptor mRNA increased by $50 \%$ at four weeks, and by $70-$ $90 \%$ at eight and 12 weeks of $\mathrm{CCl}_{4}$ treatment (figs 2B, 3B); $\mathrm{ET}_{\mathrm{B}}$ mRNA expression increased by $25 \%, 85 \%$, and $110 \%$ at 4 ,
8 , and 12 weeks of $\mathrm{CCl}_{4}$ treatment, respectively (figs $2 \mathrm{~B}, 3 \mathrm{D}$ ). $\mathrm{ET}_{\mathrm{A}}$ as well as $\mathrm{ET}_{\mathrm{B}}$ mRNA expression was approximately $20 \%$ less in TAK-044 treated rats than in saline treated rats both at eight and 12 weeks (figs 2B, 3B, 3D).

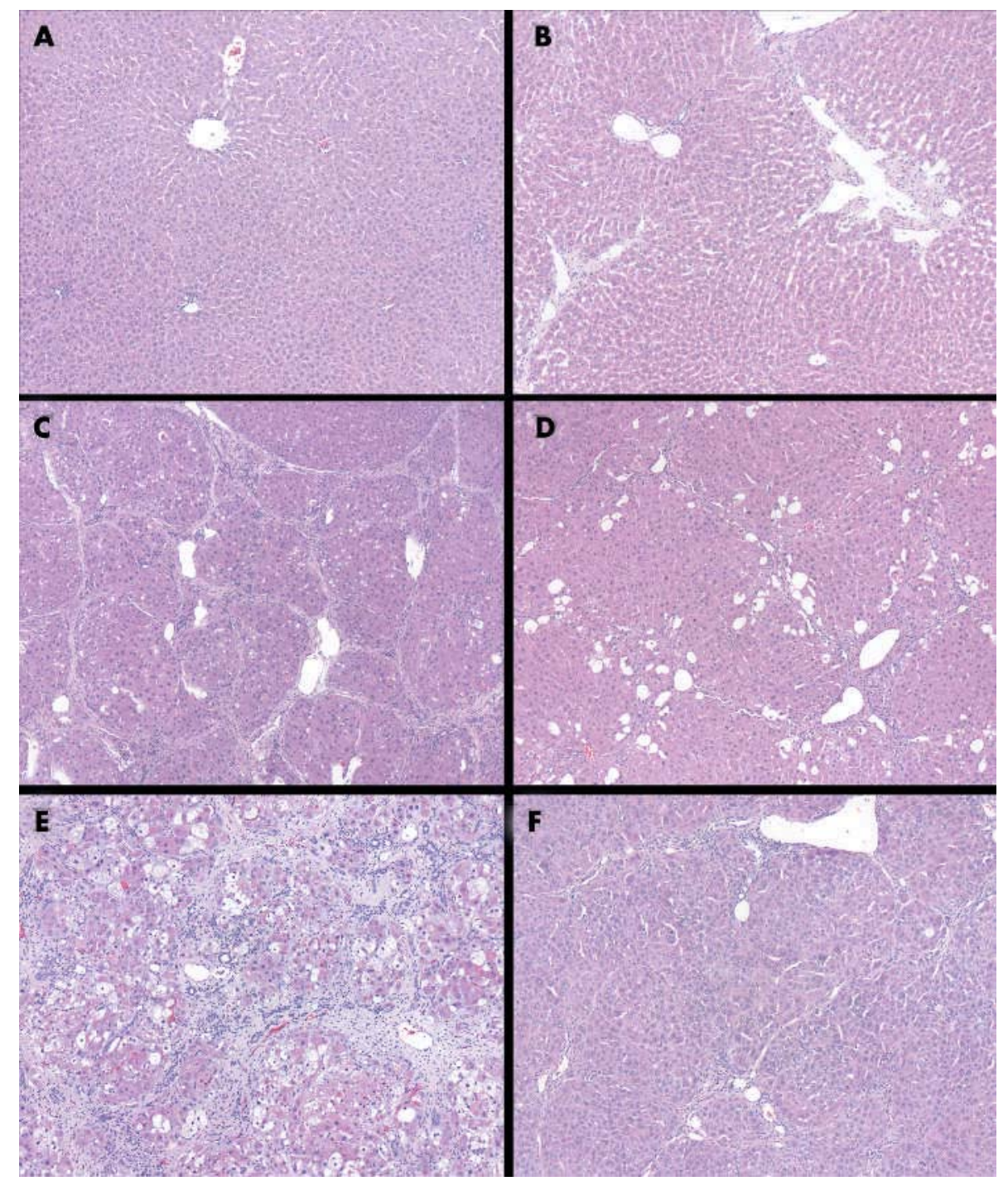

Figure 4 Hepatic histopathology during development of carbon tetrachloride $\left(\mathrm{CCl}_{4}\right)$ induced cirrhosis with or without concurrent TAK-044 treatment. Rats were treated with $\mathrm{CCl}_{4}$ for 4,8 , and 12 weeks. During $\mathrm{CCl}_{4}$ treatment between four and eight weeks or eight and 12 weeks, $50 \%$ of rats each received TAK-044 or saline. Liver sections stained with haematoxylin and eosin are shown (see methods).

(A) Control livers treated with phenobarbital only (eight weeks) show normal liver morphology. Similar histology was observed in rats treated for four and 12 weeks. (B) Four weeks of $\mathrm{CCl}_{4}$ treatment. Thin fibrous septa are present but they do not form bridging connections. (C) Eight weeks of $\mathrm{CCl}_{4}$ treatment with saline treatment between four and eight weeks.

Distortion of the liver architecture by bridging fibrosis and the formation of cirrhosis is evident. (D) Eight weeks of $\mathrm{CCl}_{4}$ treatment with concurrent TAK044 treatment between four and eight weeks. Significant reduction of liver fibrosis compared with $(C)$ is seen. (E) Twelve weeks of $\mathrm{CCl}_{4}$ treatment, with saline treatment between eight and 12 weeks. Thick bridging fibrous septa that completely destroy the liver architecture are evident. (F) Twelve weeks of $\mathrm{CCl}_{4}$ treatment with concurrent TAK-044 treatment between eight and 12 weeks. Significant reduction of liver fibrosis compared with (C) and (E) can be seen. Original magnification $\times 100$. 


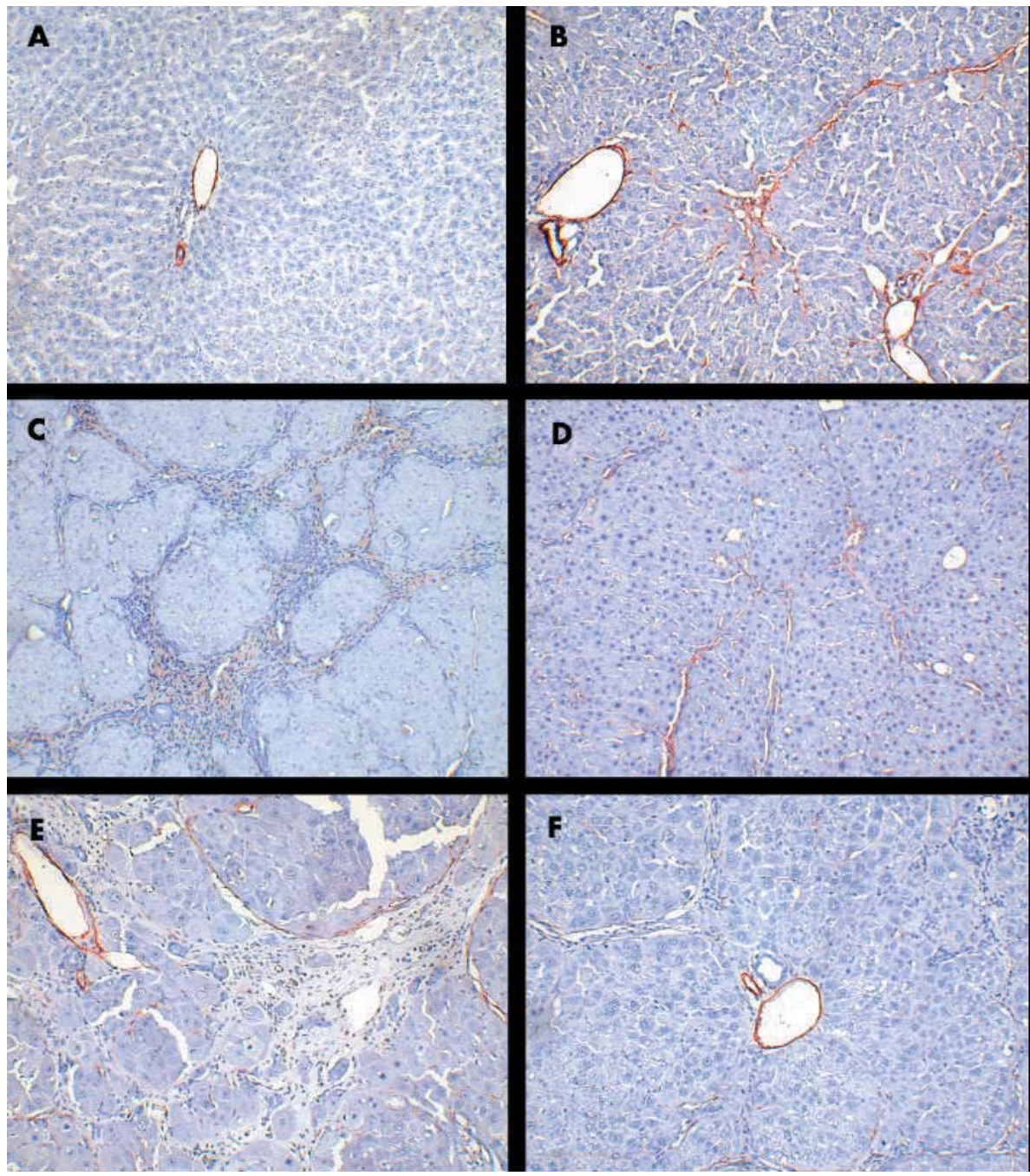

Figure 5 Expression of $\alpha$ smooth muscle actin ( $\alpha$-SMA) during the course of cirrhosis development with or without concurrent TAK-044 treatment. Rats were treated with carbon tetrachloride $\left(\mathrm{CCl}_{4}\right)$ for 4,8 , and 12 weeks. During $\mathrm{CCl}_{4}$ treatment between four and eight weeks or eight and 12 weeks, $50 \%$ of rats each received TAK-044 or saline. Liver sections were immunostained for $\alpha$-SMA. (A) Control livers treated with phenobarbital only (eight weeks). $\alpha$-SMA-positive cells are restricted to the portal vein and hepatic artery walls only. (B) Four weeks of $\mathrm{CCl}_{4}$ treatment. In addition to portal and arterial walls, $\alpha$-SMA positive cells appear within thin fibrous septae and liver parenchyma. (C) Eight weeks of $\mathrm{CCl}_{4}$ treatment with saline treatment between four and eight weeks. Abundant $\alpha$-SMA staining in the fibrous areas indicate the presence of activated hepatic stellate cells/ myofibroblasts. (D) Eight weeks of $\mathrm{CCl}_{4}$ treatment with concurrent TAK-044 treatment between four and eight weeks. The number of $\alpha$-SMA positive cells in the fibrous areas is reduced significantly. (E) Twelve weeks of $\mathrm{CCl}_{4}$ treatment with saline treatment between eight and 12 weeks. Cells in wide fibrous septum facing liver parenchyma as well as intralobular cells express $\alpha$-SMA. (F) Twelve weeks of $\mathrm{CCl}_{4}$ treatment with concurrent TAK-044 treatment between eight and 12 weeks. Number of $\alpha$-SMA positive cells is significantly decreased. Original magnification $\times 200$.

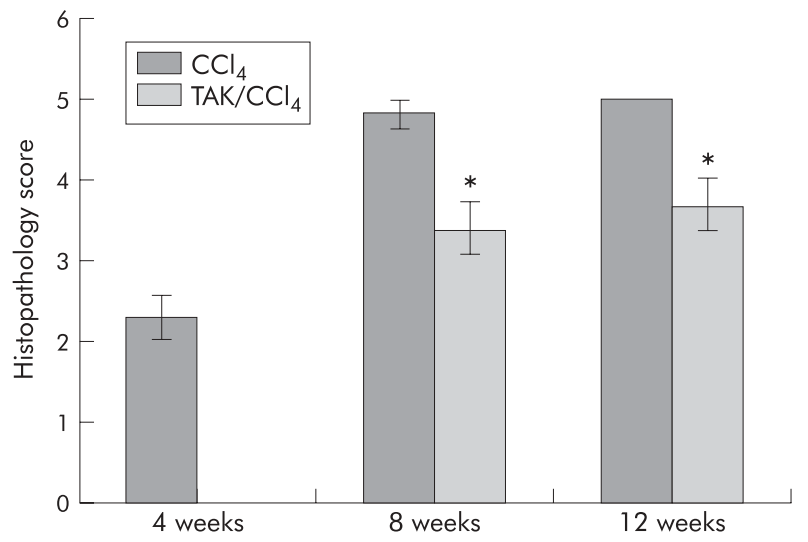

Figure 6 Histopathology score in TAK-044 treated cirrhotic rats. Histopathological assessment of cirrhotic livers after four weeks of carbon tetrachloride $\left(\mathrm{CCl}_{4}\right)$ treatment, eight weeks of $\mathrm{CCl}_{4}$ treatment with four weeks of concurrent saline or TAK-044 treatment, and 12 weeks of $\mathrm{CCl}_{4}$ treatment with four weeks of concurrent saline or TAK-044 treatment. Scores were rated between " 5 " (cirrhotic) and " 0 " (normal morphology). Results are means (SEM) of three $\mathrm{CCl}_{4}$ treated rats at four weeks, and seven rats each for $\mathrm{CCl}_{4}+$ saline or $\mathrm{CCl}_{4}+\mathrm{TAK}-044$ treatment at eight and 12 weeks. ${ }^{*} p<0.02$ versus control.

\section{General characteristics (table 1)}

The body weight of $\mathrm{CCl}_{4}$ treated rats was $25 \%, 20 \%$, and $30 \%$ lower than that of paired controls at 4, 8, and 12 weeks, respectively. TAK-044 treatment of rats receiving $\mathrm{CCl}_{4}$ improved body weight by $5 \%$ and $23 \%$, respectively, at eight and 12 weeks. The weight of the spleen increased significantly after eight and 12 weeks of $\mathrm{CCl}_{4}$ treatment; TAK-044 prevented the increase in spleen weight at eight weeks to a small extent but not at 12 weeks. All of the $\mathrm{CCl}_{4}$ treated rats developed ascites at eight and 12 weeks; the volume of ascites was nearly eight times greater at 12 weeks than at eight weeks of $\mathrm{CCl}_{4}$ treatment. TAK-044 treatment caused $50 \%$ and $75 \%$ reduction in ascites at eight and 12 weeks, respectively. The synthetic capacity of the liver was reduced in $\mathrm{CCl}_{4}$ treated rats, as indicated by decreased serum albumin, which was normalised by TAK-044 treatment. Liver injury, as estimated by serum LDH, AST, ALT, and $\gamma$-GT, also improved significantly in TAK-044 treated rats. No mortality occurred in TAK- $044+\mathrm{CCl}_{4}$ treated rats, and mortality was less than $5 \%$ in saline $+\mathrm{CCl}_{4}$ treated rats at eight and 12 weeks of treatment.

\section{Histological assessment}

Figure 4A shows normal hepatic architecture in control rats. Liver fibrosis was evident, with the beginning of septum formation after four weeks of $\mathrm{CCl}_{4}$ treatment (fig 4B). In control livers, $\alpha$-SMA positive cells were present in portal veins and hepatic arteries (fig $5 \mathrm{~A}$ ) but staining of cells in 

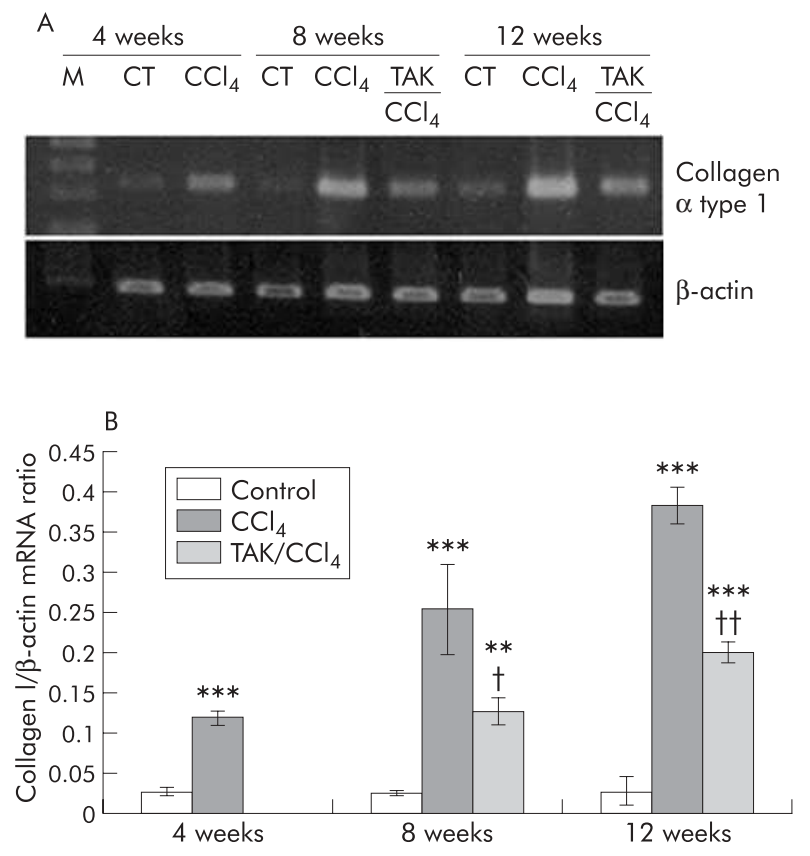

Figure 7 Effect of carbon tetrachloride $\left(\mathrm{CCl}_{4}\right)$ and TAK-044 treatment on collagen $\alpha$ type I mRNA. Rats were treated with $\mathrm{CCl}_{4}$ for 4,8 , and 12 weeks. During $\mathrm{CCl}_{4}$ treatment between four and eight weeks or eight and 12 weeks, $50 \%$ of rats each received TAK- 044 or saline.

(A) Representative gel showing mRNA expression of collagen $\alpha$ type 1 and $\beta$-actin using the same amount of cDNA in reverse transcriptasepolymerase chain reaction. (B) Bar graph showing mRNA expression of collagen $\alpha$ type 1 normalised with respect to that of $\beta$-actin, representing averages from duplicate determinations from three rats in each group. ${ }^{* *} p<0.01,{ }^{* * *} p<0.001$ versus control; $\uparrow p<0.05,+\dagger p<0.01$ versus $\mathrm{CCl}_{4}$

fibrotic tissue was also observed in rats treated with $\mathrm{CCl}_{4}$ (fig 5B). After eight weeks of $\mathrm{CCl}_{4}$ treatment, extensive fibrosis caused distortion of the liver architecture (fig 4C), with $\alpha$-SMA positive cells occupying most of the fibrous tissue (fig 5C). Concurrent TAK-044 treatment between four and eight weeks reduced the development of fibrosis (fig 4D) and decreased the number of $\alpha$-SMA positive cells in the fibrous areas (fig 5D). At 12 weeks, the pathological score and fibrosis were similar to that after eight weeks of $\mathrm{CCl}_{4}$ treatment although the fibrous bands were relatively thicker (fig $4 \mathrm{E}$ ). A substantial number of $\alpha$-SMA positive cells were observed at the interface between hepatocytes and the fibrous tissue and inside the parenchyma after 12 weeks of $\mathrm{CCl}_{4}$ treatment (fig 5E). Interestingly, however, the number of $\alpha$-SMA positive cells in the middle of fibrous tissue was reduced after 12 weeks of $\mathrm{CCl}_{4}$ treatment compared to that at eight weeks. TAK-044 treatment between eight and 12 weeks caused marked reduction of fibrosis (fig 4F) which was associated with marked reduction in the number $\alpha$-SMA positive cells (fig 5F $v$ fig 5E). A summary of the histopathology scores depicted in a bar graph (fig 6) shows significant amelioration of the pathology by TAK-044 after both eight weeks and 12 weeks of $\mathrm{CCl}_{4}$ treatment.

\section{Collagen mRNA, hydroxyproline, collagenase, and TIMP mRNA}

mRNA expression of collagen $\alpha$ type I increased respectively by 4,9 , and 13 -fold at 4,8 , and 12 weeks of $\mathrm{CCl}_{4}$ treatment (fig 7). mRNA expression of collagen I in rats treated concurrently with TAK-044 and $\mathrm{CCl}_{4}$ was $50 \%$ less than in saline $+\mathrm{CCl}_{4}$ treated rats at both eight and 12 weeks (fig 7).

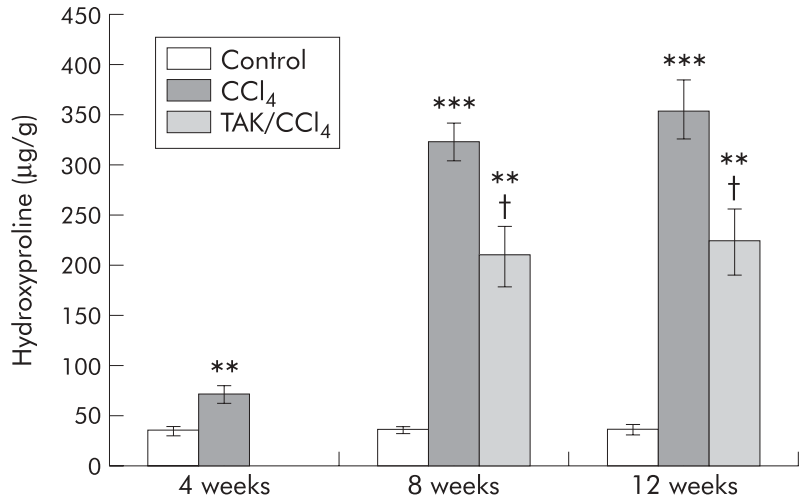

Figure 8 Effect of carbon tetrachloride $\left(\mathrm{CCl}_{4}\right)$ and TAK-044 treatment on hepatic hydroxyproline content. Rats were treated with $\mathrm{CCl}_{4}$ for 4,8 , and 12 weeks. During $\mathrm{CCl}_{4}$ treatment between four and eight weeks or eight and 12 weeks, $50 \%$ of rats each received TAK-044 or saline. Values are means (SEM) of three control and three $\mathrm{CCl}_{4}$ treated rat livers (four weeks) and three control, seven $\mathrm{CCl}_{4}+$ saline treated, and seven $\mathrm{CCl}_{4}+\mathrm{TAK}-044$ treated rat livers at eight and 12 weeks, each sample assayed in triplicate. ${ }^{* *} \mathrm{p}<0.01,{ }^{* * *} \mathrm{p}<0.001$ versus control; $\mathrm{tp}<0.05$ versus $\mathrm{CCl}_{4}$.

$\mathrm{CCl}_{4}$ treatment increased hepatic hydroxyproline by twofold at four weeks and by 10 -fold at eight and 12 weeks (fig 8). A significant (35\%) reduction in hydroxyproline occurred in rats receiving TAK-044 relative to those receiving saline between four and eight weeks as well as eight and 12 weeks of $\mathrm{CCl}_{4}$ treatment.

Hepatic collagenase activity increased by $64 \%$ at four weeks and by twofold at eight and 12 weeks of $\mathrm{CCl}_{4}$ treatment (fig 9). Concurrent TAK-044 and $\mathrm{CCl}_{4}$ treatment caused 30\% and $20 \%$ decreases in collagenase activity at eight and 12 weeks, respectively (fig 9).

Matrix metalloproteinases (MMPs) are important in liver fibrogenesis and its resolution but we were unable to obtain any conclusive evidence for changes in expression of MMP-1 and MMP-13 in $\mathrm{CCl}_{4}$ and TAK-044+CCl 4 treated rat livers (not shown). TIMP-1 and TIMP-2 modulate fibrosis by inhibiting MMPs. ${ }^{31-33}$ QRT-PCR demonstrated 33\%, 300\%, and $150 \%$ increases in TIMP-1 mRNA, and 65\%, 260\%, and

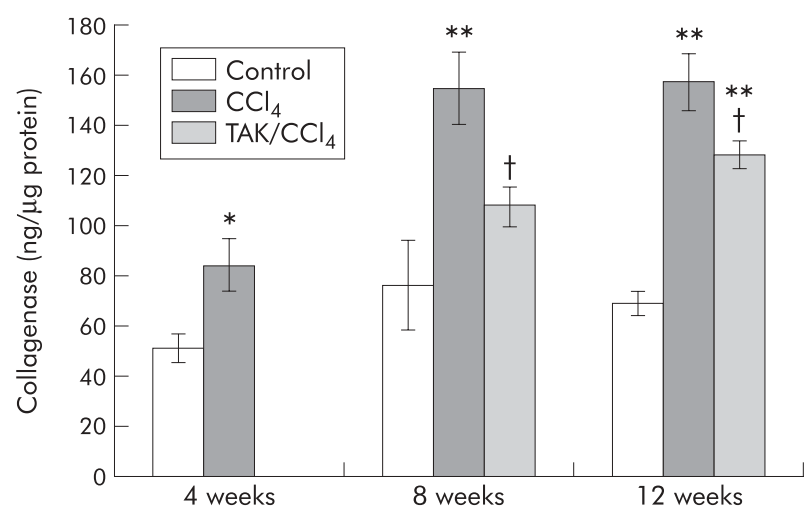

Figure 9 Effect of carbon tetrachloride $\left(\mathrm{CCl}_{4}\right)$ and TAK-044 treatment on collagenase activity. Rats were treated with $\mathrm{CCl}_{4}$ for 4,8 , and 12 weeks. During $\mathrm{CCl}_{4}$ treatment between four and eight weeks or eight and 12 weeks, $50 \%$ of rats each received TAK- 044 or saline. Collagenase activity was determined as described in the methods section. Values are means (SEM) of three control and three $\mathrm{CCl}_{4}$ treated rat livers (four weeks) and three control, seven $\mathrm{CCl}_{4}$ +saline treated, and seven $\mathrm{CCl}_{4}+\mathrm{TAK}-044$ treated rat livers at eight and 12 weeks, each sample assayed in triplicate. ${ }^{*} \mathrm{p}<0.05,{ }^{* *} \mathrm{p}<0.01$ versus control; $+\mathrm{p}<0.05$ versus $\mathrm{CCl}_{4}$. 

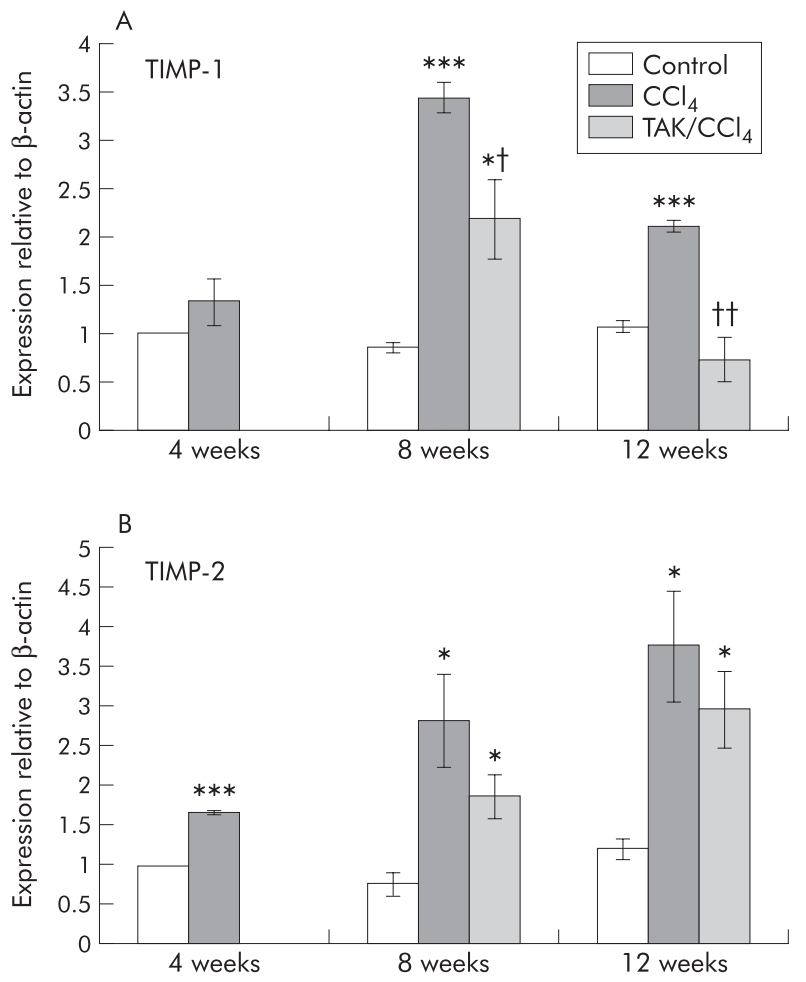

Figure 10 Real time polymerase chain reaction (PCR) for tissue inhibitor of metalloproteinase (TIMP)-1 (A) and TIMP-2 (B) mRNA expression. TIMP-1, TIMP-2, and $\beta$-actin were measured using quantitative real time PCR, as described in the methods section. TIMP-1 and TIMP-2 values were corrected using $\beta$-actin, and normalised to four week controls to facilitate comparison. Values are means (SEM) for duplicate or triplicate determinations in three separate experiments. ${ }^{*} p<0.05,{ }^{* * *} p<0.001$ versus control; $\uparrow p<0.05,+\dagger p<0.01$ versus $\mathrm{CCl}_{4}$.

$310 \%$ increases in TIMP-2 mRNA after 4,8 , and 12 weeks of $\mathrm{CCl}_{4}$ treatment, respectively (fig 10). TAK-044 reduced mRNA expression of TIMP-1 by $36 \%$ and $65 \%$, and of TIMP-2 by $34 \%$ and $22 \%$ at eight and 12 weeks, respectively.

TGF- $\boldsymbol{\beta} 1$

Hepatic TGF- $\beta 1$ content increased respectively by $0.8,8$, and 11 -fold at 4, 8, and 12 weeks of $\mathrm{CCl}_{4}$ treatment (fig 11A). TAK-044 caused nearly $60 \%$ reduction in TGF- $\beta 1$ content at both eight and 12 weeks relative to saline treated rats. Increased hepatic mRNA expression of TGF- $\beta 1$ in $\mathrm{CCl}_{4}$ treated rats (which was similarly increased at 4,8 , and 12 weeks) also decreased on treatment with TAK-044 (fig 11B, 11C).

\section{Mean arterial and portal venous pressure}

Mean arterial pressure (MAP) was not significantly different between control and $\mathrm{CCl}_{4}$ treated rats at four weeks (fig 12A). At both eight and 12 weeks of $\mathrm{CCl}_{4}$ treatment, MAP decreased by nearly 30\% compared with paired controls. Between four and eight weeks of concurrent TAK-044 treatment, MAP tended to rise but the change did not reach statistical significance. On the other hand, significant improvement (almost to normal levels) in MAP occurred on TAK-044 treatment between eight and 12 weeks (fig 12A).

Portal venous pressure increased significantly in rats treated with $\mathrm{CCl}_{4}$ for eight and 12 weeks (100-150\% increase), indicative of portal hypertension (fig 12B). In both groups, TAK-044 reduced portal hypertension remarkably,

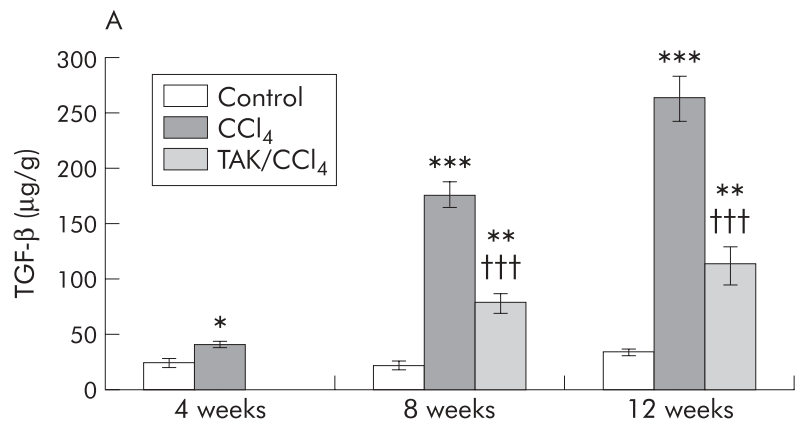

B
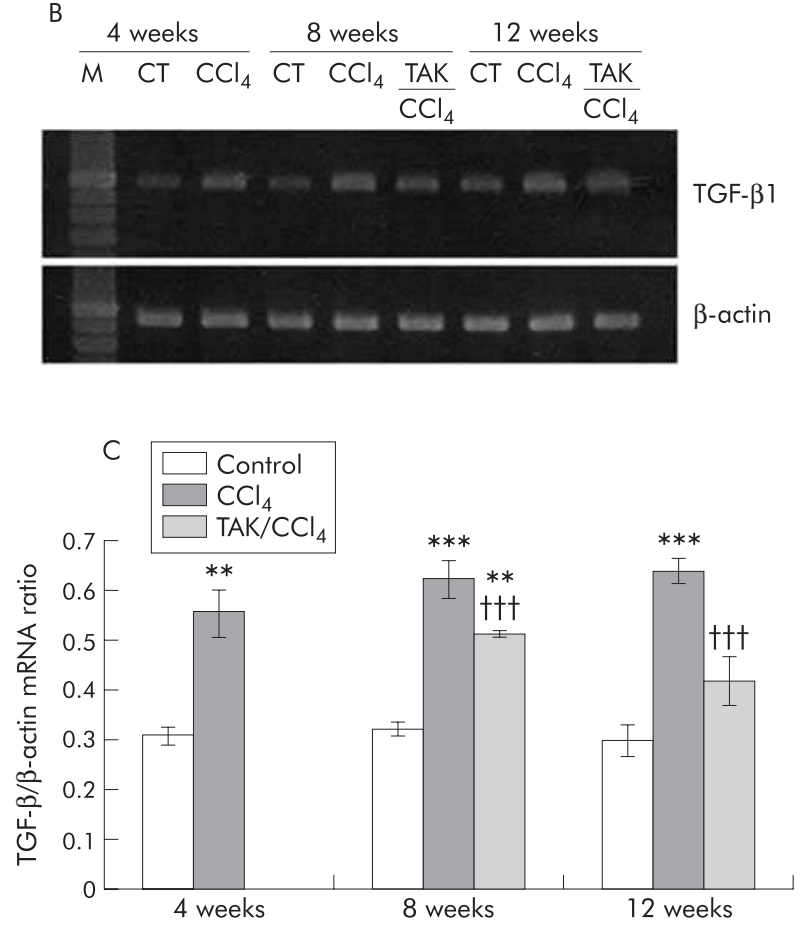

Figure 11 Effect of carbon tetrachloride $\left(\mathrm{CCl}_{4}\right)$ and TAK-044 treatment on transforming growth factor $\beta 1$ (TGF- $\beta 1$ ). Rats were treated with $\mathrm{CCl}_{4}$ for 4,8 , and 12 weeks. During $\mathrm{CCl}_{4}$ treatment between four and eight weeks or eight and 12 weeks, $50 \%$ of rats each received TAK-044 or saline. Hepatic TGF- $\beta 1$ content and its mRNA expression were determined. (A) Hepatic TGF- $\beta 1$ content. Values are means (SEM) of three control and three $\mathrm{CCl}_{4}$ treated rat livers (four weeks) and three control, seven $\mathrm{CCl}_{4}+$ saline treated, and seven CCl ${ }_{4}+\mathrm{TAK}-044$ treated rat livers at eight and 12 weeks, each sample assayed in triplicate.

(B) Representative gel showing mRNA expression of TGF- $\beta 1$ and $\beta$-actin using the same amount of CDNA in reverse transcriptase-polymerase chain reaction. (C) mRNA expression of TGF- $\beta 1$ normalised with respect to that of $\beta$-actin. Values shown are means (SEM) of three control and three $\mathrm{CCl}_{4}$ treated rat livers (four weeks) and three control, three $\mathrm{CCl}_{4}+$ saline treated, and three $\mathrm{CCl}_{4}+\mathrm{TAK}-044$ treated rat livers at eight and 12 weeks, each sample assayed in duplicate. ${ }^{*} p<0.02,{ }^{* *} p<0.01$, ${ }^{* * *} \mathrm{p}<0.001$ versus control; $\dagger+\uparrow \mathrm{p}<0.001$ versus $\mathrm{CCl}_{4}$.

with portal pressure being only $30-50 \%$ higher than in control rats.

\section{DISCUSSION}

The profound haemodynamic and metabolic effects of ET-1 in the normal liver, ${ }^{134}{ }^{35}$ progressive increase in the ET-1 system from initiation of $\mathrm{CCl}_{4}$ induced liver injury to development of cirrhosis, ${ }^{10}$ and upregulation of the ET-1 system in experimental biliary cirrhosis $^{36}$ and human cirrhosis of various aetiologies ${ }^{6-8}$ indicate that ET- 1 is a major factor in the pathogenesis and complications of the chronic 

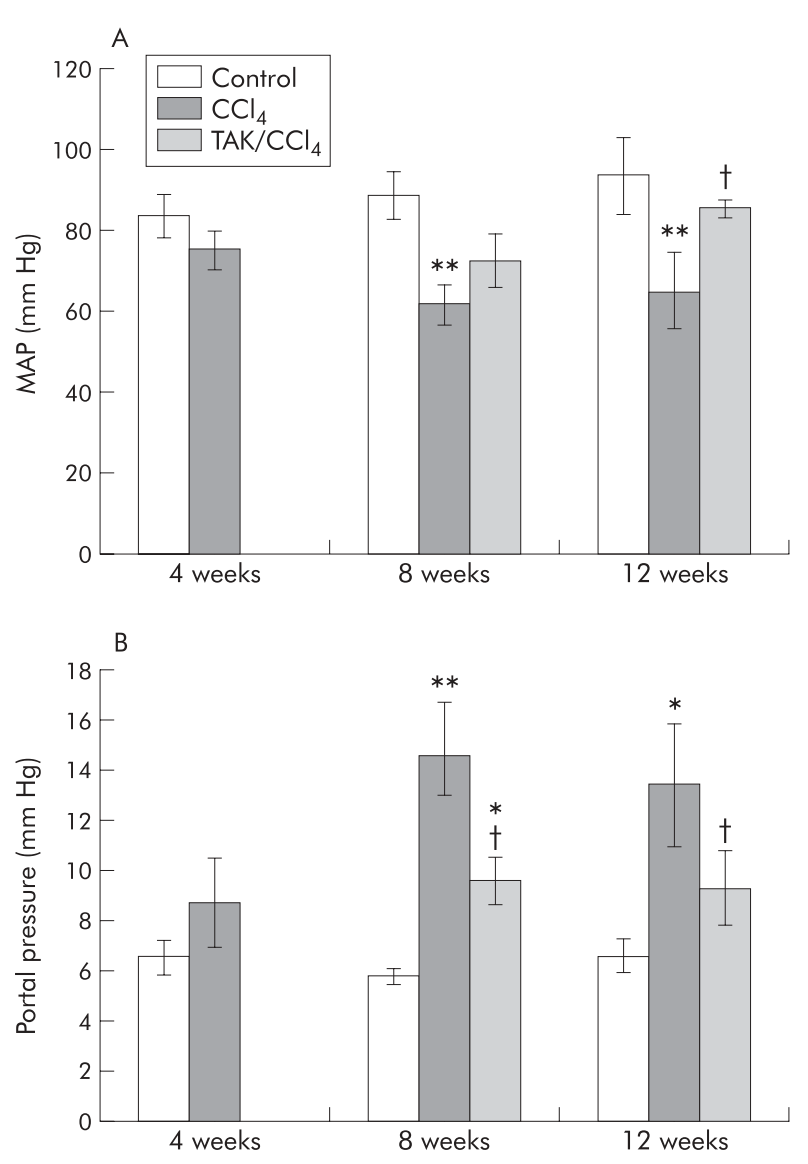

Figure 12 Effect of carbon tetrachloride $\left(\mathrm{CCl}_{4}\right)$ and TAK-044 treatment on mean arterial pressure (MAP) and portal pressure of cirrhotic rats. Rats were treated with $\mathrm{CCl}_{4}$ for 4,8 , and 12 weeks. During $\mathrm{CCl}_{4}$ treatment between four and eight weeks or eight and 12 weeks, $50 \%$ of rats each received TAK-044 or saline. (A) MAP and (B) portal venous pressure were determined. Values are means (SEM) of three control and three $\mathrm{CCl}_{4}$ treated rat livers (four weeks) and three control, seven $\mathrm{CCl}_{4}+$ saline treated, and seven $\mathrm{CCl}_{4}+\mathrm{TAK}-044$ treated rat livers at eight and 12 weeks. ${ }^{*} p<0.05,{ }^{* *} p<0.01$ versus control; $\uparrow p<0.05$ versus $\mathrm{CCl}_{4}$.

liver disease. The ET-1 receptor antagonist TAK-044 accelerates the spontaneous reversal of $\mathrm{CCl}_{4}$ induced cirrhosis in rats. ${ }^{26}$ The present investigation demonstrates that administration of TAK-044 concurrent with $\mathrm{CCl}_{4}$ arrests progression of fibrosis to cirrhosis and reverses cirrhosis.

Activated hepatic stellate cells and portal myofibroblasts accumulating in fibrous areas are primarily responsible for excessive deposition of extracellular matrix (ECM) components and architectural distortion ${ }^{37} 38$; both cell types express $\alpha$-SMA. We observed $\alpha$-SMA positive cells both within the fibrous septa and at the interphase between the parenchyma and fibrous tissue at four and eight weeks of $\mathrm{CCl}_{4}$ treatment. In the wide fibrous septa, observed at 12 weeks of $\mathrm{CCl}_{4}$ treatment, $\alpha$-SMA positive cells were found predominantly at the interphase, and a substantial number within the parenchyma. With increased deposition of the ECM, cells likely migrate to the outer region of the fibrous tissue. Rats treated with TAK-044 had substantially decreased numbers of $\alpha$-SMA positive cells and fibrous tissue deposition, morphological findings concordant with the beneficial effects of the inhibitor.

ET-1 likely mediates hepatic fibrogenesis by stimulating the synthesis of and/or by influencing the activities of mediators such as TGF- $\beta$, platelet derived growth factor, and tumour necrosis factor $\alpha^{173940}$ all of which can cause activation, proliferation, and fibrogenesis in stellate cells. ${ }^{37}$ mRNA and protein expression of the powerful fibrogenic cytokine TGF- $\beta 1$ was reduced in TAK-044 treated rats. Type I collagen is a major component of the ECM deposited in liver fibrosis, ${ }^{41}{ }^{42}$ and TAK-044 both prevented the increase in collagen $\alpha$ type I mRNA expression during $\mathrm{CCl}_{4}$ treatment between four and eight weeks, and reduced its expression remarkably at 12 weeks. TAK-044 also caused marked reduction in hepatic hydroxyproline content. Together, these results suggest that ET-1 plays an important role in fibrogenesis by modulating TGF- $\beta 1$ and collagen synthesis. However, such effects of ET-l may be indirect as ET-l stimulates synthesis of collagen and TGF- $\beta 1$ in normal but not in activated stellate cells. ${ }^{17}$

Increased deposition of collagen in the fibrotic liver is a result of its enhanced synthesis and reduced degradation. Paradoxically, hepatic collagenase activity measured in vitro is significantly increased in $\mathrm{CCl}_{4}$ treated rats (present study, and also Okazaki and Maruyama ${ }^{43}$ and Montfort and PerezTamayo ${ }^{44}$ ) and decreased by TAK-044 treatment. Either collagen synthesis far exceeds its degradation or collagenase activity measured in vitro is strongly suppressed in vivo by TIMPs which are increased in the fibrotic liver. ${ }^{45}$ The rapid decrease in TIMP expression seen during spontaneous recovery from $\mathrm{CCl}_{4}$ induced advanced fibrosis ${ }^{46}$ likely increases collagenase activity in vivo, reversing ECM deposition. This is consistent with our finding of decreased TIMP-1 and TIMP-2 expression in rats receiving TAK-044.

The present $58 \%$ and $60 \%$ decreases in portal hypertension in TAK-044 treated rats at eight and 12 weeks, respectively, are combinations of the resolution of fibrosis and inhibition of the contractile component. Acute infusion of TAK-044 in cirrhotic rats affects only the contractile component, ${ }^{10}$ giving a more modest $(20 \%)$ decrease in portal hypertension. Both ET-1 receptor subtypes appear to be critical in the haemodynamic component of portal hypertension, with sinusoidal and presinusoidal constriction caused by $\mathrm{ET}_{\mathrm{A}}$ and $\mathrm{ET}_{\mathrm{B}}$ receptors, respectively. ${ }^{13}$ Mixed $\mathrm{ET}_{\mathrm{A}}+\mathrm{ET}_{\mathrm{B}}$ antagonists reduce portal hypertension in cirrhotic rats ${ }^{10}{ }^{24} 47$ but do not affect portal pressure in normal rats. ${ }^{1024}$ Thus the haemodynamic component of portal hypertension in cirrhosis includes major participation of the upregulated $\mathrm{ET}_{\mathrm{A}}$ and $\mathrm{ET}_{\mathrm{B}}$ receptors, and increased endogenous ET-1.

Decreased MAP in cirrhosis is attributed to increased production of several vasodilatory mediators, including NO and PAF. ${ }^{48}{ }^{49}$ In the present study, MAP was found to increase in rats treated with TAK-044. Therefore, inability of the acute treatment with ET-1 receptor antagonist to improve systemic hypotension ${ }^{10}$ suggests requirement of long term antagonism of ET-1 receptors in the liver, and possibly in the systemic vasculature. As $\mathrm{ET}_{\mathrm{A}}$ antagonist is unable to alter arterial pressure in cirrhotic rats, ${ }^{22}$ our results also suggest that $\mathrm{ET}_{\mathrm{B}}$ plays a primary role in systemic hypotension in cirrhosis. Indeed, $\mathrm{ET}_{\mathrm{B}}$ has been shown to stimulate the synthesis of $\mathrm{NO}$ and PAF, respectively, in endothelial cells ${ }^{50}$ and Kupffer cells ${ }^{51}$; the latter effect is augmented in cirrhosis. ${ }^{11} \mathrm{ET}_{\mathrm{A}}$, on the other hand, seems to limit systemic hypotension as intraarterial infusion of the $\mathrm{ET}_{\mathrm{A}}$ antagonist $\mathrm{BQ}-123$ caused a greater increase in forearm blood flow in cirrhotic patients compared with normal volunteers. ${ }^{52}$

Cirrhosis causes upregulation of the hepatic ET-1 system in both rats and humans. ${ }^{6-10} 2236$ Both $\mathrm{ET}_{\mathrm{A}}$ and $\mathrm{ET}_{\mathrm{B}}$ receptors appear to play important roles in the development and complications of cirrhosis, and review of the literature suggests that simultaneous antagonism of both receptor subtypes is necessary to achieve beneficial effects. Rockey and Chung ${ }^{14}$ found that essentially concurrent administration of the mixed antagonist bosentan and $\mathrm{CCl}_{4}$ (bosentan from day $0, \mathrm{CCl}_{4}$ from day 2) significantly decreased hepatic 
collagen mRNA (stellate cells) and protein (liver section) at day 22 . This short term $(\sim 3$ week) study also showed that bosentan inhibited activation (measured as $\alpha$-SMA expression) of stellate cells. In contrast, a long term experiment ${ }^{53}$ used $\mathrm{CCl}_{4} /$ phenobarbital from week 0 and RO48-5695, a mixed $\mathrm{ET}_{\mathrm{A}} / \mathrm{ET}_{\mathrm{B}}$ inhibitor optimised from bosentan, from week 8. At week 17, cirrhotic rats had significantly elevated ALT, $\gamma$-GT, bilirubin, portal pressure, and significantly decreased MAP and serum proteins. Hepatic histology also showed cirrhotic changes. However, there was no significant normalisation of any parameter with RO 48-5695 treatment. The effectiveness of RO 48-5695 in vivo has been demonstrated in experimental models of hypercholesterolaemia, ${ }^{54} 55$ and inflammatory bowel disease and gastric ulcerogenesis ${ }^{56} 57$ but RO 48-5695 is also ineffective in the reduced renal mass model of glomerular sclerosis. ${ }^{58}$ Obviously, a comparative study of TAK-044 and RO 48-5695 in cirrhosis would be of interest.

In summary, simultaneous antagonism of both ET-1 receptor subtypes slows the progression of fibrosis to cirrhosis, and reverses cirrhosis. In addition, TAK-044 can reduce portal hypertension and systemic hypotension, major complications that are almost always present in cirrhosis. These observations, and the similarity between the changes in the hepatic ET-1 system in human and experimental cirrhosis, suggest that mixed $\mathrm{ET}_{\mathrm{A}} / \mathrm{ET}_{\mathrm{B}}$ antagonists such as TAK-044 have strong therapeutic potential in chronic liver disease.

\section{ACKNOWLEDGEMENTS}

This work was supported by a grant from the NIH (DK 54411) and a VA Merit award to CRG, and by a grant from the NIH (R43-DK602701) to VMS. TAK-044 was a kind gift of Takeda Chemical Industries Ltd, Osaka, Japan.

\section{Authors' affiliations}

C Thirunavukkarasu, Y Yang, J Fung, Department of Surgery, Thomas E Starzl Transplantation Institute, University of Pittsburgh, Pittsburgh, Pennsylvania, USA

V M Subbotin, Mirus Corporation, 505 S Rosa Rd, Madison, WI 53717, USA

S A K Harvey, Department of Ophthalmology, University of Pittsburgh, Pittsburgh, Pennsylvania, USA

C R Gandhi, Department of Surgery, Thomas E Starzl Transplantation Institute, University of Pittsburgh, Pittsburgh, Pennsylvania, USA, and Department of Pathology, Veterans Administration Medical Center, University of Pittsburgh, Pittsburgh, Pennsylvania, USA

\section{REFERENCES}

1 Gandhi CR, Stephenson K, Olson MS. Endothelin, a potent peptide agonist in the liver. J Biol Chem 1990;265:17432-5.

2 Weber KT, Sun Y, Guarda E. Structural remodeling in hypertensive heart disease and the role of hormones. J Hypertension 1994;23:869-77.

3 Hocher B, Thone-Reineke T, Rohmeiss P, et al. Endothelin- 1 transgenic mice develop glomerulosclerosis, interstitial fibrosis, and renal cysts but not hypertension. J Clin Invest 1997;99:1380-9.

4 Teder $\mathbf{P}$, Noble PW. A cytokine reborn? Endothelin-1 in pulmonary inflammation and fibrosis. Am J Respir Cell Mol Biol 2000;23:7-10.

5 Benigni A. Endothelin antagonists in renal disease. Kidney Int 2000:57:1778-94.

6 Gandhi CR, Kang Y, De Wolf A, et al. Altered endothelin homeostasis in patients undergoing liver transplantation. Liver Transpl Surg 1996;2:362-9.

7 Pinzani M, Milani S, De Franco R, et al. Endothelin 1 is overexpressed in human cirrhotic liver and exerts effects on activated hepatic stellate cells. Gastroenterology 1996;110:534-48.

8 Leivas A, Jimenez W, Bruix J, et al. Gene expression of endothelin-1 and $\mathrm{ET}_{\mathrm{A}}$ and $\mathrm{ET}_{\mathrm{B}}$ receptors in human cirrhosis: relationship with hepatic hemodynamics. J Vasc Res 1998;35:186-93.

9 Gandhi CR, Sproat LA, Subbotin VM. Increased hepatic endothelin-1 levels and endothelin receptor density in cirrhotic rats. Life Sci 1996;58:55-62.

10 Gandhi CR, Nemoto E, Watkins SC, et al. An endothelin receptor antagonist TAK-044 ameliorates carbon tetrachloride-induced acute liver injury and portal hypertension in rats. Liver 1998; 18:39-48.

11 Yang Y, Harvey SAK, Gandhi CR. Kupffer cells are a major source of plateletactivating factor in the $\mathrm{CCl}_{4}$-induced cirrhotic rat liver. $J$ Hepatol 2003;39:200-7.
12 Yang Y, Nemoto E, Harvey SAK, et al. Increased hepatic platelet activating factor (PAF) and PAF receptors in $\mathrm{CCl}_{4}$ induced liver cirrhosis. Gut 2004;53:877-93

13 Zhang JX, Baver M, Clemens MG. Vessel- and target cell-specific actions of endothelin-1 and endothelin-3 in rat liver. Am J Physiol 1995:269:G269-77.

14 Rockey DC, Chung JJ. Endothelin antagonism in experimental hepatic fibrosis. Implications for endothelin in the pathogenesis of wound healing. J Clin Invest 1996;98:1381-8

15 Kojima H, Sakurai S, Kuriyama S, et al. Endothelin-1 plays a major role in portal hypertension of biliary cirrhotic rats through endothelin receptor subtype B together with subtype A in vivo. J Hepatol 2001;34:805-11.

16 Rockey DC. Characterization of endothelin receptors mediating rat hepatic stellate cell contraction. Biochem Biophys Res Commun 1995;207:725-31.

17 Gandhi CR, Kuddus RH, Uemura T, et al. Endothelin stimulates transforming growth factor- $\beta 1$ and collagen synthesis in stellate cells from control but not cirrhotic rat liver. Eur J Pharmacol 2000;406:311-18.

18 McLean EK, McLean AE, Sutton PM. Instant cirrhosis. An improved method for producing cirrhosis of the liver in rats by simultaneous administration of carbon tetrachloride and phenobarbitone. Br J Exp Pathol 1969;50:502-6.

19 Proctor E, Chatamra K. High yield micronodular cirrhosis in the rat. Gastroenterology 1982;83:1 183-90

20 Hernandez-Munoz R, Diaz-Munoz M, Suarez J, et al. Adenosine partially prevents cirrhosis induced by carbon tetrachloride in rats. Hepatology 1990;12:242-8.

21 Cho J-J, Hocher B, Herbst $\mathrm{H}$, et al. An oral endothelin-A receptor antagonist blocks collagen synthesis and deposition in advanced rat liver fibrosis. Gastroenterology 2000;118:1169-78.

22 Leivas A, Jimenez W, Lamas S, et al. Endothelin 1 does not play a major role in the homeostasis of arterial pressure in cirrhotic rats with ascites. Gastroenterology 1995;108:1842-8

23 Nishida T, Huang T-P, Seiyama A, et al. Endothelin A-receptor blockade worsens endotoxin-induced hepatic microcirculatory changes and necrosis. Gastroenterology 1998;115:412-20.

24 Kojima H, Yamao J, Tsujimoto T, et al. Mixed endothelin receptor antagonist, SB209670, decreases portal pressure in biliary cirrhotic rats in vivo by reducing portal venous system resistance. J Hepatol 2000;32:43-50.

25 Anselmi K, Subbotin VM, Nemoto EM, et al. Accelerated reversal of carbon tetrachloride-induced cirrhosis in rats by endothelin receptor antagonist TAK044. J Gastroenterol Hepatol 2002;17:589-97.

26 Gandhi CR, Kuddus RH, Nemoto EM, et al. Endotoxin treatment causes an upregulation of the endothelin system in the liver: Amelioration of increased portal resistance by endothelin receptor antagonism. J Gastroenterol Hepatol 2001;16:61-9.

27 Bradbury P, Gordon KC. Connective tissue and stain. In: Bancroft JD, Stevens A, eds. Theory and practice of histological techniques. New York: Churchill Livingston Press, 1990:119-42.

28 Skalli O, Pelte M-F, Peclet $M-C$, et al. Alpha-smooth muscle actin, a differentiation marker of smooth muscle cells, is present in microfilamentous bundles of pericytes. J Histochem Cytochem 1989;37:315-21.

29 Subbotin V, Sun $\mathrm{H}$, Aitouche A, et al. Abrogation of chronic rejection in a murine model of aortic allotransplantation by prior induction of donor-specific tolerance. Transplantation 1997;64:690-5.

30 Jamall MJ, Finelli VN, Que Hee SS. A simple method to determine nanogram levels of 4-hydroxyproline in biological tissues. Ann Biochem $1981 ; 112: 70-5$.

31 Herbst H, Wege T, Milani S, et al. Tissue inhibitor of metalloproteinase-1 and -2 RNA expression in rat and human liver fibrosis. Am J Pathol 1997; 150:1647-59.

32 Iredale JP, Goddard S, Murphy G, et al. Tissue inhibitor of metalloproteinase-I and interstitial collagenase expression in autoimmune chronic active hepatitis and activated human hepatic lipocytes. Clin Sci (Lond) 1995;89:75-81.

33 Takahara T, Furui K, Funaki J, et al. Increased expression of matrix metalloproteinase-II in experimental liver fibrosis in rats. Hepatology 1995;21:787-95.

34 Serradeil-Le Gal C, Jouneaux C, Sanchez-Bueno A, et al. Endothelin action in rat liver. Receptors, free $\mathrm{Ca}^{2+}$ oscillations, and activation of glycogenolysis. J Clin Invest 1991;87:133-8

35 Tran-Thi TA, Kawada N, Decker K. Regulation of endothelin-1 action on the perfused rat liver. FEBS Lett 1993;318:353-7.

36 Rothermund L, Leggewie S, Schwarz A, et al. Regulation of the hepatic endothelin system in advanced biliary fibrosis in rats. Clin Chem Lab Med 2000;38:507-12

37 Friedman SL. Molecular regulation of hepatic fibrosis, an integrated cellular response to tissue injury. J Biol Chem 2000;275:2247-50.

38 Knittel T, Kobold D, Piscaglia F, et al. Localization of liver myofibroblasts and hepatic stellate cells in normal and diseased rat livers: distinct roles of (myoffibroblast subpopulations in hepatic tissue repair. Histochem Cell Biol $1999 ; 112: 387-401$

39 Hahn AW, Resink TJ, Bernhardt J, et al. Stimulation of autocrine plateletderived growth factor AA-homodimer and transforming growth factor $\beta$ in vascular smooth muscle cells. Biochem Biophys Res Commun 1991;178:1451-8.

40 Ruetten $\mathrm{H}$, Thiemermann C. Endothelin-1 stimulates the biosynthesis of tumor necrosis factor in macrophages: ET receptors, signal transduction and inhibition by dexamethasone. J Physiol Pharmacol 1997;48:675-88.

41 Seyer JM, Hutcheson ET, Kang AH. Collagen polymorphism in normal and cirrhotic human liver. Clin Invest 1977;59:241-8.

42 Rojkind M, Giambrone MA, Biempica L. Collagen types in normal and cirrhotic liver. Gastroenterology 1979;76:710-19.

43 Okazaki I, Maruyama K. Collagenase activity in experimental hepatic fibrosis. Nature 1974;252:49-50. 
44 Montfort I, Perez-Tamayo R. Collagenase in experimental carbon tetrachloride cirrhosis of the liver. Am J Pathol 1978;92:41 1-20.

45 Iredale JP, Benyon RC, Arthur MJP, et al. Tissue inhibitor metalloproteinase-1 messenger RNA expression is enhanced relative to interstitial collagenase messenger RNA in experimental liver injury and fibrosis. Hepatology 1996;24:176-84.

46 Iredale JP, Benyon RC, Pickering J, et al. Mechanisms of spontaneous resolution of rat liver fibrosis. Hepatic stellate cell apoptosis and reduced hepatic expression of metalloproteinase inhibitors. J Clin Invest 1998; 102:538-49.

47 Rockey DC, Weisiger RA. Endothelin induced contractility of stellate cells from normal and cirrhotic rat liver: implications for regulation of portal pressure and resistance. Hepatology 1996;24:233-40.

48 Ros J, Jiminez W, Lamas S, et al. Nitric oxide production in arterial vessels of cirrhotic rats. Hepatology 1995;21:554-60.

49 Schrier RW, Caramelo C. Hemodynamic and hormonal alterations in hepatic cirrhosis. In: M Epstein, eds. The kidney in liver disease. New York: Elsevier Biochemicals, 1988:309-27.

50 Tsukahara H, Ende H, Magazine HI, et al. Molecular and functional characterization of of the non-isopeptide-selective ETB receptor in endothelial cells: Receptor coupling to nitric oxide synthase. J Biol Chem 1994;269:21778-85
51 Mustafa SB Gandhi CR, Harvey SAK, et al. Endothelin stimulates platelet activating factor synthesis by cultured rat Kupffer cells. Hepatology 1995;21:545-53. 52 Helmy A, Newby DE, Jalan R, et al. Enhanced vasodilatation to endothelin antagonism in patients with compensated cirrhosis and the role of nitric oxide. Gut 2003:52:410-15.

53 Poo JL, Jimenez W, Munoz RM, et al. Chronic blockade of endothelin receptors in cirrhotic rats: hepatic and hemodynamic effects. Gastroenterology 1999;116:161-7.

54 Best PJ, McKenna CJ, Hasdai D, et al. Chronic endothelin receptor antagonism preserves coronary endothelial function in experimental hypercholesterolemia. Circulation 1999;99:1747-52.

55 Taner CB, Severson SR, Best PJ, et al. Treatment with endothelin-receptor antagonists increases NOS activity in hypercholesterolemia. J Appl Physiol 2001;90:816-20.

56 Padol I, Huang JQ, Hunt RH. Anti-ulcerogenic properties of endothelin receptor antagonists in the rat. Aliment Pharmacol Ther 1999;13:537-44.

57 Padol I, Huang JQ, Hogaboam CM, et al. Therapeutic effects of the endothelin receptor antagonist Ro 48-5695 in the TNBS/DNBS rat model of colitis. Eur J Gastroenterol Hepatol 2000;12:257-65.

58 Clozel M, Qiu C, Osterwalder R, et al. Effects of nonpeptide endothelin receptor antagonists in rats with reduced renal mass. J Cardiovasc Pharmacol 1999;33:611-18.

\section{EDITOR'S QUIZ: GI SNAPSHOT}

Answer

From question on page 1000

During menses, colonoscopy showed a large multilobulate polyp (3.5 cm in diameter) of the sigmoid colon with a hyperaemic and friable mucosa (fig 1). Histological examination showed a normal mucosa with the presence of some branched crypts and marked inflammation in the lamina propria.

During the intermenstrual period (on the eighth day of the cycle), polyp size had decreased; its surface appeared only slightly lobulate without friability and with hyperaemia, which was reduced at two red spots (fig 2). Histopathological evaluation showed the presence of endometriotic foci in the context of a mucosa containing branched crypts.

The patient was submitted to a gynaecological examination which was found to be normal. Pelvic and vaginal ultrasounds did not show evidence of endometriotic lesions. Magnetic resonance imaging detected a $1.8 \mathrm{~cm}$ area with a $\mathrm{T} 1$ hyperintense and $\mathrm{T} 2$ hypointense signal in the sigmoid wall.

Medical treatment with leuprolide acetate depot, a gonadotropin releasing hormone agonist (GnRH-a) (3.75 mg intramuscularly every four weeks for three months) was started. Abdominal pain and bloody diarrhoea promptly disappeared. At the four month follow up she was still free of symptoms and anaemia had reversed (haemoglobin $12.3 \mathrm{~g} / \mathrm{dl}$ ). At the one year follow up, colonoscopy showed a flat lesion without hyperaemia or friability at the site of the endometriotic polyp. Histological examination of multiple biopsies was normal and a magnetic resonance imaging showed complete disappearance of the previously detected lesion. After 18 months of follow up, the patient remains completely asymptomatic.

Endometriosis is defined as the presence of endometrial tissue in sites other than the uterus. The rectosigmoid is the most frequently involved site. Heterotopic endometrium generally adheres to serosal surfaces and may invade the bowel wall. However, appearance as a polyp is rarely reported. Infiltration of the mucosa is uncommon and therefore the endoscopic biopsy may not be diagnostic. The variable appearance on endoscopy is related to the cyclic endometrial tissue changes.

Surgical resection is indicated for massive rectal bleeding or obstruction but the role of surgery is less clear when the clinical course is not life threatening. Medical treatment with a $\mathrm{GnRH}-\mathrm{a}$ is commonly used in pelvic endometriosis but studies on its efficacy in intestinal endometriosis are still lacking.

To our knowledge this is the first case reported in the literature showing that an endometriotic colonic polyp may be successfully treated by medical therapy with a GnRH-a. This case further illustrates that endometriosis may appear as a colonic polyp and that polypectomy is not curative. 